\title{
Vertical inhibition of the mTORC1/mTORC2/PI3K pathway shows synergistic effects against melanoma in vitro and in vivo
}

\author{
Johannes Werzowa, Stefan Koehrer, Sabine Strommer, Daniel Cejka, Thorsten Füreder, Volker Wacheck* \\ From 16th Scientific Symposium of the Austrian Pharmacological Society (APHAR) \\ Vienna, Austria. 25-27 November 2010
}

\section{Background}

The phosphatidyl inositol 3-kinase/mammalian target of rapamycin (PI3K/mTOR) pathway has been shown to be involved in the development of melanoma. PI-103 is a novel kinase inhibitor blocking PI3K class IA and mTOR complex 1 and 2. Here, we studied the effect of targeting the $\mathrm{PI} 3 \mathrm{~K} / \mathrm{mTORC} 1 / \mathrm{mTORC} 2$ pathway by PI-103 and rapamycin in melanoma cells and a melanoma mouse model.

\section{Materials and methods}

Human melanoma cell lines (518A2, 607B, A375, MelJuso, SKMel-28) were treated with PI-103 and assessed for cell viability, apoptosis and cell cycle distribution. $\mathrm{PI} 3 \mathrm{~K} / \mathrm{mTOR}$ protein target modulation was measured by Western-blotting. For siRNA experiments, cells were transfected with $50 \mathrm{nmol} / \mathrm{L}$ Silencer ${ }^{\circ}$ Select siRNA against PIK3CA (p110 $\alpha$ catalytic subunit of PI3K). For in vivo studies athymic nude mice were inoculated with 518A2 cells and treated daily with PI-103 $(20 \mathrm{mg} / \mathrm{kg} / \mathrm{d})$ and sirolimus $(1 \mathrm{mg} / \mathrm{kg} / \mathrm{d})$. Paraffin-embedded xenograft sections were stained for p-AKT (Ser473) and p-S6 (Ser240+244).

\section{Results}

Dual targeting of PI3K and mTOR by PI-103 induced apoptosis and cell cycle arrest, and inhibited viability of melanoma cells in vitro. Combined treatment with PI-103 and the prototypic mTORC1 inhibitor rapamycin led to synergistic suppression of AKT and ribosomal S6 protein phosphorylation and to induction of apoptosis.

\footnotetext{
* Correspondence: volker.wacheck@meduniwien.ac.at Department of Clinical Pharmacology, Medical University of Vienna, 1090 Vienna, Austria
}

In vivo, PI-103 and rapamycin displayed only modest single agent activity but the combination significantly reduced tumor growth compared to both single agents.

\section{Conclusions}

Taken together, our study underscores the importance of the PI3K/mTORC1/mTORC2 pathway in melanoma and demonstrates that rational combination of compounds that lead to an optimal blockade of a critical pathway ("vertical inhibition") may provide an effective strategy for future treatment of melanoma.

Published: 16 November 2010

doi:10.1186/1471-2210-10-S1-A42

Cite this article as: Werzowa et al:: Vertical inhibition of the mTORC1/ mTORC2/PI3K pathway shows synergistic effects against melanoma in vitro and in vivo. BMC Pharmacology 2010 10(Suppl 1):A42.

Submit your next manuscript to BioMed Central and take full advantage of:

- Convenient online submission

- Thorough peer review

- No space constraints or color figure charges

- Immediate publication on acceptance

- Inclusion in PubMed, CAS, Scopus and Google Scholar

- Research which is freely available for redistribution 